\title{
Improving Access to Justice through Law Graduate Post-Study Community Service in South Africa
}

\section{P.E.R}

Pioneer in peer-reviewed, open access online law publications

Author

David Holness

https://orcid.org/0000-0002-1635-0078

\section{Affiliation}

University of KwaZulu-Natal, South Africa

\section{Email Holness@ukzn.ac.za}

Date Submission

21 January 2019

Date Revised

10 December 2019

Date Accepted

12 December 2019

Date published

16 January 2020

Editor Prof T Mmusinyane

How to cite this article

Holness D "Improving Access to Justice through Law Graduate

Post-Study Community Service in South Africa" PER / PELJ 2020(23) - DOI

http://dx.doi.org/10.17159/1727-

3781/2020/v23i0a5968

\section{Copyright}

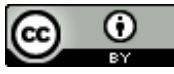

DOI

http://dx.doi.org/10.17159/1727-

3781/2020/v23i0a5968

\begin{abstract}
Access to justice for all in South Africa, as most clearly set out in sections 34 and 35 of the Constitution of the Republic of South Africa, 1996, is necessary to realise various other fundamental rights and to improve living standards. There are insufficient free legal services available to the indigent in South Africa, especially in civil matters, thereby often making meaningful access to justice unattainable. This study considers possible approaches, challenges and opportunities for law graduate community service in South Africa (hereinafter "community service") to expand the ambit and impact of free legal services to the indigent. This would promote the constitutional imperative of access to justice, focussing on civil matters. This study concentrates on the access to justice potential of and challenges to such community service. Such challenges will be shown to include its proper utilisation and control through the adequate supervision of graduates. This paper argues that graduate community service has the capacity to promote better access to justice and hence that steps should be taken for its introduction in some form.
\end{abstract}

Community service and means for law graduates to perform this as a necessary part of vocational training before entering the legal profession are provided for in section 29 of the Legal Practice Act 28 of 2014 (LPA). But despite parts of the Act being operative, community service is neither in operation nor do regulations yet exist for its implementation.

The specific vocational training element(s) for law graduates is worthy of separate study and is not the focus of this paper. Such a separate study would include opportunity creation - such as gaining the necessary practical experience and the establishment of employment opportunities - and training challenges for graduates during community service.

In the pre-LPA era it would have been necessary to focus more on whether community service for law graduates should be included in legislation or not as part of graduates' vocational training and as a key component of free legal service delivery. Some such arguments are alluded to as community service has yet to be implemented and its implementation is not a fait accompli. But because it is now included in the LPA as a legal aid service delivery possibility, this study instead focusses on the need for the effective and appropriate implementation and operation of community service to turn the requirements and encouraging promise of the LPA on community service into reality. The paper explores issues such as the necessary and appropriate supervision and placement of law graduates completing community service. The research very briefly touches on whether community service would best be compulsory for graduates as part of their vocational training or merely one possible route towards admission to the legal profession. Lessons are sought for legal community service in South Africa from existing medical post-study community service schemes as to the role which such schemes have played in expanded service provision and impediments experienced in reaching such goals. These lessons are applied to proposals for the implementation and operation of law graduate community service.

This study considers how community service could and should be a key component of a multifaceted and co-ordinated approach to expand and improve free legal services for the indigent in civil matters in South Africa with its gross inequality, unemployment and poverty. For this goal to be realised, there must be mechanisms for its effective roll-out and operation.

\section{Keywords}

Law graduates; community service; Legal Practice Act; South Africa; constitutional rights; legal aid; civil legal matters; supervision. 


\section{Introduction}

In the South African justice system many people cannot afford to use the courts because of the expenses involved, or because they are ignorant of their rights. ${ }^{1}$ Section 34 of the Constitution of the Republic of South Africa, 1996 (the Constitution) promises a "fair trial", which has application to civil matters and it has been argued includes legal representation in certain civil cases. $^{2}$ Legal representation under section 34 is less directly stated than criminal legal aid provisions in and legal representation through section 35 of the Constitution. ${ }^{3}$ In addition, different empirical studies have shown the very limited provision of free legal services in civil matters available in South Africa. ${ }^{4}$ Significantly, these studies have also shown that the minimal provision of free legal services in civil matters is geographically skewed; rural areas being far more poorly serviced than urban centres.

The inadequacy of the free legal services offered to poor and marginalised people in South Africa becomes important to consider in the light of key interrelated challenges of very high unemployment, extreme poverty and gross inequality. ${ }^{5}$ Massive socio-economic challenges are still being faced by large swathes of people many years after the advent of democracy. This paper considers possible approaches to, challenges to and opportunities for law graduate community service in South Africa (hereinafter referred to as "community service") as a means to counter these serious socio-economic ills using improved access to legal assistance as a vehicle for greater social justice. The central aspect of this paper is the potential role of community service in expanding and improving free legal services in civil cases to indigent people for improved social justice.

This paper explores the graduate community service provided for in section 29 of the Legal Practice Act 28 of 2014 (LPA), although it is not yet in place - nor is its implementation even a fait accompli. ${ }^{6}$ The author will argue that

David Holness. BA LLB PG Dip in Higher Ed (Rhodes) LLM LLD (NMMU). Director, University of KwaZulu-Natal Law Clinic, South Africa. E-mail: Holness@ukzn.ac.za. ORCiD: https://orcid.org/0000-0002-1635-0078.

McQuoid-Mason 1999 Windsor YB Access Just 2.

Holness 2013 SJ 18.

Holness 2013 SJ 18.

For example: Vawda 2005 Obiter 237; Van As 2005 Obiter 187.

South Africa's National Development Plan 2030 is authority for government having identified these massive socio-economic challenges. Government of the Republic of South Africa 2017 https://www.gov.za/issues/national-development-plan-2030.

$6 \quad$ As of January 2018, the first step in implementing the Legal Practice Act 28 of 2014 (the LPA) occurred via the Legal Practice Council (to regulate the legal profession) beginning to operate. Some aspects of the LPA came into force on 1 November 2018 , but various other aspects will be phased in only over time. For example, in terms of this paper's focus, in terms of the Legal Practice Amendment Act 16 of 2017 
because current legal services in South Africa overwhelmingly focus on criminal as opposed to civil legal aid, community service must logically focus on civil legal aid.

Specific vocational training opportunities for graduates in a community service scheme, such as gaining the necessary practical experience and the creation of employment opportunities, plus the challenges they are likely to face, merit separate study and largely fall beyond the ambit of this study. Notwithstanding this focus, an effective and valuable community service system would have to incorporate the development of the practical skills of those who have completed community service, as well as the supervision of their work. The need for the appropriate supervision of those undertaking community service is therefore stressed.

The implementation of community service would not be without significant challenges in positioning it as an important element of the necessary provision of free legal service. The author therefore contemplates the implementation of community service for better and expanded service provision through an analysis of lessons from existing medical post-study community service in South Africa (albeit the degree of experience of graduates performing such a service differs). Such comparisons highlight the opportunities and challenges likely to be faced in implementing law community service.

It will be submitted that community service would be a valuable cog in the wheel of a much-needed civil legal aid for improved access to justice. This will be subject to the possession of necessary ingredients such as adequate resources for a community service scheme, and the proper supervision of its graduates.

In the absence of the LPA it would have been necessary to focus more on normative arguments for and against graduate community service. Because of the provision for graduate community service in the LPA, however, this study focusses instead on proposals for its roll-out and operation.

The paper first considers community service in the LPA and the context for its implementation. It then examines the medical graduate community service scheme experience as a comparator for legal graduate community service. $^{7}$ The rationale for the comparison between medical and legal community service is made. Finally, submissions are made as to the

read together with s 120 of the LPA, the "Community Service" provisions in s 29 of the LPA are not yet in force.

This paper does not seek to analyse law post-study community service abroad. 
possible implementation and operation strategies for law community service.

\section{Law graduate community service in South Africa in the Legal Practice Act}

The parts of Section 29 of the LPA most relevant to this study state: 8

Community service

(1) The Minister must, after consultation with the Council, prescribe the requirements for community service from a date to be determined by the Minister, and such requirements may include-
(a) community service as a component of practical vocational training by candidate legal practitioners; ${ }^{9}$ or
(b) a minimum period of recurring community service by practising legal practitioners upon which continued enrolment as a legal practitioner is dependent.

(2) Community service for the purposes of this section may include, but is not limited, to the following:
(a) Service in the State, approved by the Minister, in consultation with the Council;
(b) service at the South African Human Rights Commission;
(c) service, without any remuneration, as a judicial officer in the case of legal practitioners, including as a commissioner in the small claims courts;
(d) the provision of legal education and training on behalf of the Council, or on behalf of an academic institution or non- governmental organisation; or
(e) any other service which the candidate legal practitioner or the legal practitioner may want to perform, with the approval of the Minister.

It appears to be illogical or at least confusing for section 29 of the LPA to have conflated into this one section two very largely distinct concepts. "Community service as a component of practical vocational training by candidate legal practitioners", which as per section 29(1)(a) applies to

8 Emphasis added, as it is s 29(1)(a) of the LPA that applies specifically to graduate community service.

$9 \quad$ These graduate community service requirements, if introduced, would apply equally to "trainee" advocates and attorneys - collectively termed "candidate legal practitioners" in the LPA. The LPA now governs both arms of the legal profession (attorneys and advocates, termed "legal practitioners") under the umbrella of the South African Legal Practice Council established in terms of s 4 of the Act. 
graduate community service, is distinct from pro bono work by already admitted legal practitioners/lawyers (in section 29(1)(b)). ${ }^{10}$ On an overly simplistic basis it could be understood why the legislature may have combined pro bono work by already admitted lawyers with graduate community service. This is because both focus on the provision of free legal services to indigent people. But there are a number of distinct differences between the two concepts. For example, pro bono work by admitted lawyers (hereinafter pro bono) relates to the amount of unpaid services to needy and qualifying clients required of admitted lawyers annually. The word unpaid, in so far as it relates to lawyers' pro bono work, is stressed as graduate community service would almost certainly entail graduates being paid some form of basic salary or stipend during their period of community service in order for them to subsist. Furthermore, the type of "community service" work which legally inexperienced graduates would appropriately be able to perform must be very different from the work that could be expected of an admitted lawyer. Finally, an admitted lawyer performing a small proportion of his/her work time pro bono is in a very different position to a graduate who would very likely do this full-time during a part of his/her vocational training.

Equally bemusing from the perspective of community service in section 29 is that section 29(2) clearly applies mainly to pro bono work by already admitted lawyers. For instance, both the reference in section 29(2)(c) to acting for free as a "judicial officer", and section 29(2)(d)'s "provision of legal education and training on behalf of the Council" must apply only to pro bono work by already admitted lawyers. Such types of work (like acting as a judicial officer) have no application whatsoever to law graduates who are not yet even legal practitioners as defined in the LPA.

Other critiques of section 29(2) could also be made. For example, there are also various well-established providers of free legal services beyond "service in the State" (typically at Legal Aid South Africa) or "service at the South African Human Rights Commission" for whom those undertaking community service could appropriately work. Such legal aid providers include organisations like the Legal Resources Centre, Lawyers for Humans Rights and university law clinics. Not specifically listing as a category for community service work in section 29(2) such non-profit organisations then requires an unnecessarily bureaucratic application for "approval by the Minister, in consultation with the Council" for community service to be served at such a registered legal aid provider. ${ }^{11}$ From the perspective of

10 This paper will often refer to admitted "legal practitioners" as "lawyers".

11 The Minister is that of Justice and Constitutional Development (hereinafter referred to as "the Minister"). 
sourcing appropriate places for graduates to perform community service (which requires appropriate supervision), placement at such legal non-profit organisations would be logical and would provide greater capacity to such organisations.

Flowing from the previous three paragraphs, insufficient detail is given to the "community service for candidate legal practitioners" part of section 29, and crucially regulations for its roll-out and operation are not in existence. The legislators thus included graduate community service as a likely or at the very least possible prerequisite for entry into the profession, yet have not stated exactly what graduate community service is, or how it could be implemented, funded and regulated.

A necessary first step would be for "The Minister ... (to) prescribe the requirements for community service ..." by way of regulations. The reason why it cannot be said that graduate community service will definitely become part of South Africa's legal framework is because of the permissive element within section 29(1), that: "The Minister must, after consultation with the Council, prescribe the requirements for community service from a date to be determined by the Minister, and such requirements may include - " (own emphasis added). In other words, the LPA requires community service, but the legislation gives the Minister some discretion as to its form. However, in so far as section 29 requires the Minister to prescribe community service and then specifically sets out graduate community service and pro bono work by admitted lawyers as ways in which this may be done, it would be illogical and regressive for the legislature not to have intended the Minister to introduce community service for candidate legal practitioners. The discretion given to the Minister could be logically utilised by a phasing in of community service at pilot delivery sites and/or making community service one way in which law graduates could perform their necessary vocational training (or part thereof) for admission into the profession. ${ }^{12}$ The Minister exercising their discretion in either or both of the ways set out in the previous sentence would make the implementation logistics more viable - such as sourcing the funding of graduates' salaries and reaching a point where the adequate supervision of graduates will be in place.

\section{Defining graduate community service for South Africa}

Partly due to the lack of clarity in section 29 , it is necessary to properly define what is meant by community service for graduates. For clinical psychologists in South Africa, "community service entails graduate

12 Such issues as community service being voluntary or compulsory should be the subject of dialogue with relevant stakeholders such as the legal profession, government and civil society. 
professionals working in a state facility for a mandatory period on completion of their internships and academic requirements..., as a prerequisite for professional registration". ${ }^{13}$

This definition will suffice as a starting point for law community service, with three possible exceptions or initial exceptions. Firstly, a community service year could conceivably come before an internship period, the latter being something like a year as a candidate legal practitioner in a firm of attorneys. ${ }^{14}$ Secondly, in terms of the necessary capacity for the placement and supervision of law graduates and for creating a greater geographical footprint of work, it might be necessary and valuable for placements to occur at legal aid providers beyond just state-owned entities as mentioned above. Thirdly, in terms of the roll-out of law community service in relation to issues such as the limited available funding and supervision, it may be that it would or should not have to be a compulsory route for entry into the profession. Graduate community service pilot projects could be introduced and evaluated before decisions in these regards are made.

\section{The context in South Africa for the implementation of law graduate community service}

\subsection{The socio-economic context}

Unless community service would play a noteworthy part in improving access to justice, its implementation would be counter-productive. According to de Klerk, "Social justice has been defined as referring to the fair distribution of health, housing, welfare, education and legal resources in society". ${ }^{15}$ It is in this context of a country with gross inequality, much of the population living in deep poverty, and very high levels of unemployment, that implementing community service as a means of promoting improved access to justice in civil matters becomes increasingly relevant to stimulate social justice. A linked point is that in South Africa where many people have limited education and cannot pay for their own lawyer, sometimes obtaining just legal advice where formal legal representation may not be necessary is valuable. A period of community service could play a quite significant role in improving access to justice through some form of legal advice and/or representation within the context of the existing limited legal aid provision described below.

\footnotetext{
13 Pillay and Harvey 2006 SAJP.

14 The question whether community service should take place in the year after a graduate's LLB or the year after that is not addressed in this paper. 


\subsection{The constitutional context for the provision of civil legal aid}

It has been argued that there is a constitutional justification for free legal services in certain civil matters in South Africa and that the enjoyment of this right may often assist vulnerable residents' access to other constitutionally protected rights. ${ }^{16}$ In other words, it could be considered a gateway or leverage right. This argument is based largely on the "fair trial" promise in section 34 of the Constitution, as read with other rights in the Bill of Rights (such as the right to equality in section 9), for civil legal aid to be provided in appropriate circumstances to sufficiently financially needy clients within available resources. A "right to civil legal aid" in certain circumstances must be considered in how community service would have to align with applicable constitutional provisions pertaining to access to justice.

\section{Community service best suited to civil as opposed to criminal legal aid}

It could be pertinently asked why this study proposes community service within the context of free legal services for the indigent in civil as opposed to criminal matters in South Africa. Separate studies and statistics have shown the major need for better access to justice in civil matters in South Africa and hence why the expansion of civil over criminal legal aid must be a current priority. ${ }^{17}$ The key rationale for this is that there is incomparably greater provision of "legal aid" (broadly construed) in criminal as opposed to civil matters in South Africa, as set out below. ${ }^{18}$

The solely state-owned Legal Aid South Africa (LASA) comprehensively provides legal aid to criminal accused in South Africa. It is by far the largest provider of legal aid to the indigent. The fact that LASA's expenditure, staffing and case output/clients assisted (in the region of $87 \%$ in each one of these categories) is on criminal as opposed to civil matters means that

Holness 2013 SJ 5.

See fn 4 above as to studies in this regard and the statistics bearing this out.

The concept of "legal aid" used in this paper is a broad one. Free legal services to clients who are invariably indigent and otherwise vulnerable socio-economically, and within the context of South Africa's often complex adversarial legal system, may take the form of "legal aid" by admitted lawyers working for non-profit organisations or via the state-owned Legal Aid South Africa. But as would be the case with graduate community service, all free legal services which contribute to greater access to justice may and often do go beyond legal aid in such a narrow context to broader free legal services such as those provided by law students in university law clinics, pro bono work by admitted lawyers and legal assistance from community-based paralegals. For analyses of these other forms of free legal services in South Africa see Holness 2013b PELJ 129-164; Holness 2013 SJ 1-21; and Holness 2013a PELJ 328-349. 
mechanisms need to be sought to more comprehensively and appropriately assist indigent, vulnerable people with adequate civil legal assistance. In LASA's annual reports each year from 2012/2013 to 2016/2017 almost exactly $87 \%$ of their cases were criminal compared with $13 \%$ being civil. ${ }^{19}$ The need for expanded civil legal aid is also reflected in LASA's reports for the above years, which specifically note in positive terms a relative increase in the number of civil cases it has undertaken, a need to further do so and an espoused aim to continue to do so. Yet LASA's own statistics in their annual reports reflect that the proportion of civil versus criminal cases has actually changed extremely little between 2012 and 2017. Very minimal growth at best in LASA's civil work is unsurprising when one notes that even in $2016 / 2017$, only $11.9 \%$ of LASA's professional staff were allocated to civil matters. ${ }^{20}$ It is unrealistic for LASA to hope that its civil legal output will increase to any noticeable extent, if at all, in the above circumstances.

Whilst legal non-profit organisations (NPOs), such as Lawyers for Human Rights, the Legal Resources Centre, SECTION27 and university law clinics do focus their work on free civil legal services, the impact they are able to make is limited by various factors. For example, there are not many of them, they are almost entirely limited to large urban centres and their work (often due to funding limitations) focusses on assisting people in those geographical areas and within their often narrow niche areas of focus and expertise. ${ }^{21}$ Flowing from the limited capacity, geographical footprint and nature of legal assistance provided by legal NPOs, their case numbers are very low in comparison with LASA's. It has also been shown above how LASA's work is considerably focussed on criminal cases. This paragraph again shows why this study looks towards the potential role of a graduate community service in expanding the provision of civil legal aid, as opposed to the already far more comprehensively provided criminal legal aid. The call for expanded civil legal aid in South Africa should not be seen as downplaying the importance of criminal legal aid. Criminal legal aid is absolutely necessary and is in accordance with the requirements of the non-

19 LASA 2017 http://www.legal-aid.co.za/wp-content/uploads/2017/09/ANR-Legal-AidSA_2017.pdf.

20 LASA 2017 http://www.legal-aid.co.za/wp-content/uploads/2017/09/ANR-Legal-AidSA_2017.pdf.

21 An example is the Legal Resources Centre, which has centres only in Cape Town, Makhanda, Durban and Johannesburg, plus just two satellite offices, and limits its focus to specific strategic litigation. LRC $2018 \mathrm{http} / / / \mathrm{lrc}$.org.za/contact/.This is dwarfed by LASA's 64 justice centres, 64 satellite offices, 6 regional offices and 1 national office plus their huge case volume. In 2016/2017 alone, LASA opened 444 962 new files and gave legal advice to a further 322964 people. LASA 2017 http://www.legal-aid.co.za/wp-content/uploads/2017/09/ANR-Legal-Aid-

SA_2017.pdf. 
derogable section 35 of the Constitution. But with a glaring need for much greater civil legal aid services, the latter's expansion is most necessary.

The legal need for community service is heightened when one takes cognisance of the fact that with the establishment of democracy in South Africa, many legal NPOs and public interest law firms are finding their funding under threat. Donors prefer to deal directly with governments rather than with large numbers of NPOs. ${ }^{22}$ In the case of public interest lawyering, many donors believe that with a democratic government in place, the responsibility for providing legal services falls on the state and should hence come out of its budget. ${ }^{23}$

In so far as many people need legal assistance in civil matters, ways to appropriately utilise community service in civil legal aid should be identified for implementation. For example, one way of capacitating legal NPOs would be by way of placing graduates funded by the state in such organisations in a community service scheme.

\section{How graduate community service would probably provide value in legal service provision and expansion}

Students for Law and Social Justice, a law student organisation that promotes access to justice and community service for all lawyers and law students, states that community service for law graduates has two aims. One is the provision of basic legal services to the indigent and the second is the provision of practical training to graduates that they do not obtain in their studies, thus exposing them to the realities of the challenging daily lives of most South Africans. ${ }^{24}$

The availability of free legal services in South Africa is important for two obvious and related reasons. First, the socio-economic context means that large swathes of the population require legal services for adequate access to justice as one means for countering the gross inequality and poverty under which so many people are living. Whilst having access to some form of legal assistance would not be a quick-fix to these massive challenges, the law should be a vehicle to enhance positive social change, and in order to harness this people often require legal assistance. Second, the high cost of employing private lawyers makes paying for their services entirely out of the reach of all but the economically elite. The Deputy Minister of the Department of Justice and Constitutional Development noted that South Africa's legal fees were "astronomically high" compared with those of other

McQuoid-Mason Windsor YB Access Just 11.

McQuoid-Mason Windsor YB Access Just 11.

Liat-Davis in Manyathi-Jele 2013 De Rebus 8. 
parts of the world. ${ }^{25}$ There is therefore a need for greater free legal services for those in dire need of such assistance. This paper has already stressed the opportunity for community service to play a role in improving the lives of vulnerable people through giving them better access to justice. The question that needs to be answered, then, is what form such assistance would take and how it should operate.

An initial issue would be the provision of basic legal advice or information, even where no formal legal representation is necessary. This last point is made through recognising that no legal right can be realised unless the right-holder is aware of it and knows how to exercise it. The probable value of a legal advice role for graduates would be hard to dispute, especially for advice with civil legal problems when considering a fairly recent initiative introduced by LASA. That initiative is a telephonic legal advice line facility, including a "Please call me" free sms service for call-backs so as not to limit the service to those who are able to afford the call. In 2016/2017 alone, LASA's Annual report reflected 41,777 items of advice or legal information were given via their telephonic legal advice line. ${ }^{26}$ Almost all of this advice was given for civil as opposed to criminal matters.

The role of graduates in a community service scheme certainly need not (and it is submitted should not) be limited to the provision of basic legal advice/information only for its value to be appropriately harnessed. After all, candidate legal practitioners are currently part of legal service provision (supervised by their principals) which typically extends beyond just providing basic legal advice or information to clients. For example, graduates are well placed to conduct both initial and follow-up consultations with clients, for whom files are opened and formal legal representation is provided. Where a client's case would require referral to a specialised organisation or lawyer acting pro bono, it would have to be ensured that the referral is made to the appropriate body or individual and that the graduate has added value to that client. What is meant by "adding value" is that instead of simply advising a client that s/he should seek the legal help of a particular organisation or lawyer, the graduate should perform all the preparatory work that would be useful to the organisation or lawyer receiving the referral. For example, taking a comprehensive initial consultation note, performing appropriate research, and gathering documentation (such as medical records in a medical malpractice case).

A separate study has identified the positive role which senior law students are already playing in expanding legal services for indigent clients in South

25 In Manyathi-Jele 2013 De Rebus 10.

26 LASA 2017 http://www.legal-aid.co.za/wp-content/uploads/2017/09/ANR-Legal-AidSA_2017.pdf. 
Africa as part of the well-supervised work at their universities' law clinics in clinical legal education programmes. ${ }^{27}$ Along similar lines, another study has highlighted the role of community-based paralegals in the provision of basic legal aid services, especially in underserviced rural areas, albeit again with the necessary safe-guards to ensure the quality of the services provided - such as appropriate paralegal training and oversight. ${ }^{28}$ The existing role of students in university law clinics and paralegals in expanding legal aid services is worthwhile noting in the context of community service because if students and paralegals are playing such a positive role, then it should certainly be the case that LLB graduates should be even better placed to grow legal aid services.

Perhaps the greatest challenge for the implementation of community service for law graduates is how community service would be rolled out and operated. In considering this challenge, this paper will next consider experiences, lessons and best practices from existing community service programmes for graduate South African doctors (and a few points on clinical psychologists) and then apply those to law community service. A brief historical context to community service will be provided before those comparative community service experiences are explored.

\section{Post-study community service historically}

Post-study service programmes have existed in different parts of the world since the early $20^{\text {th }}$ century, mainly in the field of health care. For example, in the Soviet Union from 1920, Mexico from 1936 and in Norway from 1954. ${ }^{29}$ South Africa adopted this type of programme (albeit for undoubtedly dubious purposes from a human rights perspective) in the apartheid years in the form of compulsory military service for white men. ${ }^{30}$

In post-apartheid South Africa, programmes and strategies towards addressing inequalities were introduced in certain aspects of the public sector, not the least in healthcare. The establishment of community service could also be said to hark back to the days of a very active NPO sector in South Africa. According to McQuoid-Mason, one of the very few benefits of the oppressive apartheid regime was the development of a vibrant NPO

27 Holness 2013a PELJ 328-349.

28 Holness 2013 JJS 78-105. This study showed that the legal work of communitybased paralegals in South Africa is almost entirely in civil matters. Likewise, this very dominant civil work focus has been shown to be the case for university (and other) law clinics. Holness 2013a PELJ 328-349.

29 Omole, Marincowitz, and Ogunbanjo 2005 SAFP 56.

30 See generally Perold and Omar Community Service in Higher Education 1-131. 
community, which included several organisations like university law clinics, which were engaged in public interest lawyering and voluntary work. ${ }^{31}$

As far back as 1997 the late Chief Justice Chaskalson was a strong advocate for graduate community service in South Africa, based primarily on the need for more legal services to be made available to disadvantaged and marginalised people. ${ }^{32}$ In the light of South Africa's massive focus on criminal as opposed to civil legal aid, it would be very likely that Chaskalson would have supported the need for graduate community service to be focussed on civil legal services.

\section{Medical post-study community service in South Africa}

\subsection{Why the comparison with law community service is relevant}

Existing community service for graduate doctors would not be identical for law graduates in terms of these medical graduates having already been admitted as community service "doctors", thereby changing the supervision dynamic for those overseeing their work. It is important to note, however, that community service is still a necessary part of a graduate's journey towards full participation in the medical profession. This study considers the comparison relevant for various other reasons too. Medical community service operates within the same socio-economic context as that described above. There are other commonalities with proposed law graduate community service like the professional service nature of medical and legal services and the importance of access to medical and legal services as basic government deliverables. Medical community service is also analysed because it has been in place for some time and appears to offer some insights into how law community service could appropriately increase access to legal services whilst attempting to avoid or ameliorate some of the most likely pitfalls and challenges.

\subsection{Introduction to medical community service in South Africa}

Since 1998 a graduate in medicine must satisfactorily complete a year's community service for the state (and paid for by the state) as a condition of being allowed to practice thereafter as a healthcare professional. ${ }^{33}$ Whether

$31 \quad$ McQuoid-Mason 1999 Windsor YB Access Just 8.

32 Chaskalson 1997 http://www.derebus.org.za/category/issues/December-1997/.

33 PHILA 1996 http://www.healthlink.org.za/pphc/Phila/mandserv.htm. According to the National Department of Health "PHILA is the Nguni name for the 'Door to Health or Life'. The essence of life (ukuphila) is being in good health. The National Department of Health's PHILA programme encourages all South Africans to BE INSPIRED TO LIVE." See Department of Health 2019 http://phila.org.za/. This requirement extends beyond doctors to other medical professionals, but this paper 
law community service should be compulsory for all law graduates, as opposed to a voluntary method of vocational training (or perhaps piloted in certain areas initially) will be briefly considered below.

The primary aim of medical community service is to ensure improved access to healthcare, with the subsidiary aims being to provide graduates with the chance to develop skills, knowledge and critical thinking for their professional development. ${ }^{34}$ There are clear commonalities with law community service via the augmentation of the services offered by the state whilst simultaneously improving the practical skills of graduates.

\subsection{Some key general aspects of medical community service and lessons for the legal sphere}

The introduction of medical community service can be seen to a large degree to have flowed from there being a considerable shortage of healthcare professionals in the country's state facilities, particularly in disadvantaged rural areas. Community service doctors are placed in designated geographical areas in need of medical services. ${ }^{35}$ This results in the graduate doctors often having to relocate to an isolated area far away from their support structures for their community service period. The need for support structures to fill these gaps should be noted from the perspective of introducing law community service. From the perspective of the shortage of legal services for the indigent and the geographical imbalance of the available services, as set out above, notably in civil matters, this basis for community service definitely mirrors health care community service.

Not surprisingly, the unequal provision of healthcare services has very often been a relic of apartheid, with black South Africans on the whole still being under-serviced. Community service is one method whereby government is attempting to address this legacy of unequal development as part of a bid to transform racially segregated healthcare into universal primary health care, particularly for underserviced areas. In coming to this conclusion a particular study confirmed that the mental health system remains drastically under-resourced and there exists significant inequality in the distribution of resources provincially and amongst certain racial groups. ${ }^{36}$ The Constitution protects healthcare rights ${ }^{37}$ and a number of laws and policies relate to the realisation of health care rights. For example, the National Health Care Act

limits its focus to doctors, while including some aspects of the community service programme for clinical psychologists.

34 Department of Health 2006 http://www.doh.gov.za/docs/pr/2006/pr0105.html.

35 PHILA 1996 http://www.healthlink.org.za/pphc/Phila/mandserv.htm.

36 Padfield 2013 PPSA 63.

37 See ss 12(2), 24(a), 27(1)(a), 27(3), 28(1)(c), 35(2)(e) of the Constitution. 
61 of 2003 is aimed at making effective health services available to the population equitably and efficiently, and at establishing a national health system that will provide people with the best possible health services that available resources can afford. This was the case even before current plans for the implementation of the National Health Insurance Policy. ${ }^{38}$

The problem in the public healthcare sphere, as with many other aspects of South African service delivery, has chiefly been and remains that of implementation. The policies, laws and regulations in place have often either not been properly applied or have not translated into adequate service delivery. Despite the fact that the Constitution guarantees equality for all and protects health rights, there are still many barriers that people face in accessing adequate health care services. ${ }^{39}$ People living in poor, rural communities are most affected by these barriers. It is in response to such challenges that medical community service was introduced.

The challenges and other issues raised in the previous paragraph for the provision of healthcare services are extremely similar to those of free legal service provision. For example, there are constitutional imperatives for their provision and there is a great need for the expansion of the services offered. However, the Department of Health is at least tapping the resource of supervised graduates in expanding available healthcare services, something that is not yet being done in relation to legal aid services. This paper has illustrated the need for a wider net of civil legal aid. Law graduate community service could go some way to expanding these free legal services, but law is far behind the public healthcare service insofar as medical community service exists and is implemented in a framework of existing policies and regulations. As set out above for law community service, there has still been no indication from the Minister if or when a legal community service will be implemented and as a precursor to its implementation when the pertinent requirements by way of regulations and policies will be put in place. Furthermore, were such regulations and policies to be put in place, one lesson to be learnt from the healthcare sector is that even once legislation, regulations and policies are in place, the value of the service provided will relate to the quality of the implementation and rather than the aspirations of those who devise the system. Hence, the regulatory framework for community service for law graduates must make provision for

38 National Health Insurance Policy Published under GN 627 in GG 40955 of 30 June 2017.

39 De Vos 2007 https://dullahomarinstitute.org.za/socio-economic-rights/research-andpublications/resource-book/Chapter\%208\%20-\%20Health\%20Care\%20Rights.pdf. 
the satisfactory implementation of the regulations and policy, and must include appropriate checks and safeguards.

Critically, the regulations applicable to the vocational training of candidate attorneys and pupil advocates (under the umbrella of the LPA) gazetted in August 2018 makes no mention whatsoever of community service as part of the vocational training of these candidate legal practitioners. ${ }^{40}$ In other words, the Minister did not take the opportunity - at that obvious juncture, as the door had been opened for its introduction in section 29 of the LPA to introduce some form of community service in the regulations applicable to candidate legal practitioners' vocational training. Whether community service was to have been provided for in the regulations as a compulsory element of admission to the profession or as one part of one route towards admission (the latter could have been piloted in certain sites) would not have been nearly as important as the introduction of at least some form of graduate community service as a means of providing greater access to justice. This lacuna in the gazetted regulations for candidate legal practitioners amounts to taking a regressive step, and one which should be remedied by way of amending the regulations.

\subsection{Some specific challenges encountered in the medical community service programme and lessons to be learnt from these}

Omole and others have found that unclear policy guidelines in the first year of the implementation of the medical community service programme led to highly variable graduate placements: less than 25 per cent of the community service doctors were placed in rural hospitals, whilst 55 per cent were working in regional, tertiary and specialised hospitals. ${ }^{41}$ There was therefore only a limited success in the distribution of health personnel, in particular in rural areas where the services were often most needed. The simple but important lesson to be learnt from this is that the placement of law graduates would be pivotal to a community service scheme's effectiveness. Law graduates would need to be placed - with the necessary supervision of suitably qualified and experienced lawyers - where the greatest need for civil legal aid is shown to exist. In order to establish where the greatest needs exists, one must establish the extent and nature of the legal aid service needed and what legal aid services are already available in a locality

\footnotetext{
40 GN R921 in GG 41879 of 31 August 2018. Regulation 6 relates to the vocational training requirements for the admission of Candidate Attorneys, and Regulation 7 to the admission requirements for Pupil Advocates. Omole, Marincowitz and Ogunbanjo 2005 SAFP 55.
} 
to meet those needs. This was done in an empirical study of the eThekwini metropole. ${ }^{42}$

An ideal situation in relation to continuity of legal service provision would be for a law graduate placed in a particular locality to remain there after the completion of his/her community service. This might be possible by way of a graduate's being incentivised to stay in the community service placement area after admission as a legal practitioner. As was astutely noted in the medical sphere, "for the sake of continuity it is better to have a doctor in a post for five years than five doctors for one year each." 43 This should be considered in respect of law graduates who wish to make the provision of free legal services as a possible career path in locations of their choice. For example, such a graduate could be given a job offer by LASA for a period after the successful completion of his/her service in the same area as $s / h e$ performed community service.

An analysis of community service clinical psychologists' work in Western Cape prisons finds limited resources to be an institutional challenge. ${ }^{44}$ Similarly, a lack of resources such as the internet, email, telephone and fax facilities would greatly hamper a law graduate in his/her work.

In a self-study of her psychology community service year, Padfield raises various needs and challenges to her effective operation. Some of these issues include a lack of the privacy needed to consult with one's client/patient (often linked with confidentiality requirements) and a lack of regular access to the client/patient. ${ }^{45}$ These requirements would apply directly to any community service year in the legal sphere. A law graduate would require private office space for (confidential) client consultations. A graduate would also need adequate access to clients in so far as clients' lack of finances might well limit their ability to meet with a community service graduate in the context of the legislated timeframes applicable in the legal system. In various studies analysed by Padfield on health care community service, a common linguistic challenge was encountered with the graduate being typically fluent in English and not fluent in the local language. ${ }^{46}$ This leads to difficulties when it comes to meaningfully communicating with clients/patients. This would certainly be an issue to overcome when it comes to law community service, in particular in rural areas where fluency in

\footnotetext{
$42 \quad$ Holness Coordinating Free Legal Services.

43 Conco and Reid 2012 http://www.hst.org.za/uploads/files/chapter17_99pdf.

44 Rohleder, Miller and Smith 2006 SAJP 800.

45 Padfield 2013 PPSA 64.

$46 \quad$ Padfield 2013 PPSA 76.
} 
English is much less common. English is the de facto language of legal practice. But such linguistic challenges are far from insurmountable, through the placement of graduates who are sufficiently fluent in the main language spoken in a particular area or through the use of translators.

Padfield also describes her experience of what she terms the "referral pipeline" as being "problematic: informal at best; chaotic at worst". ${ }^{47}$ This point goes to the heart of a necessary consideration of where and how an indigent person accesses free legal services in civil matters and whether such services meet their legal needs. The problem flows from the need for government service provision (be it in a medical, legal, or in another sphere) together with other service providers like NPOs, to be better co-ordinated. ${ }^{48}$

Kautzky and Tollman cite certain studies of medical community service in South Africa, evidencing insufficient orientation for graduates and often space for improvement in the supervision of their work. ${ }^{49}$ These challenges will be equally applicable to law community service and regulations, and those in control of the roll-out of a legal community service scheme will have to take careful heed of these issues. For example, a graduate would have to be properly orientated as to his/her role in a community service scheme as well as the specific legal issues most pressing in the area where $s /$ he is placed. A larger and more continuing issue for law graduates in their community service is the need for sufficient and appropriate oversight of their work in so far as they will not yet have been admitted as legal practitioners. Emdon of ProBono.org notes that supervision and mentorship would be essential during community service to alleviate the fear of unqualified lawyers being "let loose" on poor people. ${ }^{50}$ Supervision would need to be undertaken by suitably experienced and appropriate persons. What is meant by this is that such supervisors would be working in areas of law that they have appropriate expertise in and in which they have adequate years of experience.

Then there is the equally important challenge of how to ensure that the supervision of those performing law community service is actually of an adequate standard and/or diligently performed regardless of whether the person doing the supervision is sufficiently experienced and has a good knowledge of the work being done under him/her. If the supervision is more a case of ticking a box to say supervision has been provided, then such

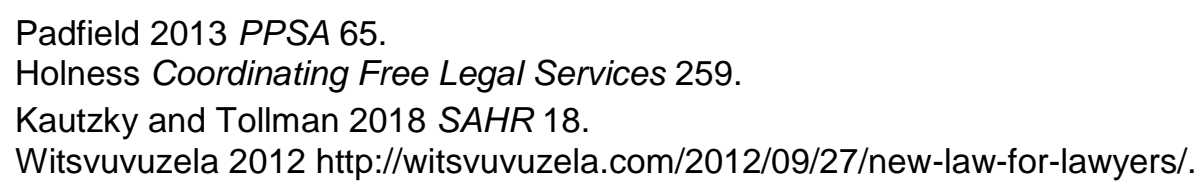


"supervision" would be of no value and would be a huge factor in reducing the value of the legal services graduates could appositely and ethically provide. A separate study looked at the role of admitted legal practitioners in South Africa, providing a prescribed number of hours of compulsory pro bono work performed annually. ${ }^{51}$ The study referred to above argues that one valuable means by which admitted lawyers could perform their pro bono hours would be where the work of a graduate was well matched with the supervisor's work. But it was shown that it was exceptional for a South African lawyer to actually fulfil his/her pro bono hours, and no sanctions are in place for non-compliance nor, crucially in the context of the point being made, are any checks made on the quality of the work done. ${ }^{52}$ Notwithstanding the existing problems of lawyers actually performing their pro bono obligations, on the grounds that legal practitioners are required to act ethically in all their work, so too those rules would require the proper supervision of graduates under their watch, were that to be the means by which they could discharge their pro bono obligations.

\section{Law graduate community service in South Africa: quo vadis?}

Given 8.4 above, it might be thought that so many difficulties have been encountered in the medical community service programme that its value could be questioned. This impression must be firmly dispelled. After the first phase of the implementation of the medical community service programme, Reid and Conco concluded that it was an overall success in providing improved healthcare. ${ }^{53}$ Such success has often been experienced, even abroad in places like Puerto Rico. A particular case study in Puerto Rico before that prior to the introduction of the community service programme 16 of 78 municipalities had no physician whatsoever. But once community service was introduced, it was shown that all 78 municipalities had at least one doctor. ${ }^{54}$ A South African study has shown that hospital managers perceive community service to have had a positive impact on the supply of the required personnel, health service delivery and patient care. ${ }^{55}$ Quite simply, the value of community service by graduate doctors in increasing, and the improvement to some degree of service provision is almost impossible to gainsay, notwithstanding the system's being far from perfect. It is submitted that whilst the manner in which law graduate community service is implemented should be the subject of careful planning resulting

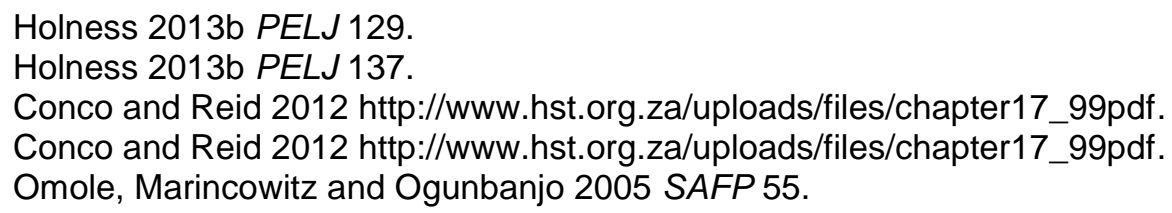


in appropriate policy and regulations, the likelihood of its improving access to justice via the ready provision of legal services is so great that government would be remiss not to take steps towards its introduction.

The remainder of this section will highlight some other problems relating to law graduate community service roll-out which would need to be considered, without seeking to provide conclusive solutions as to these.

Government will have to sufficiently allocate funds for a law community service scheme. Whilst it may be argued that government cannot afford to do this, it is argued that in terms of the value of having greater access to justice for those in need of legal assistance, it cannot afford not to do so. But the South African government's genuine commitment to legal aidrelated access to justice could be questioned, given the major cut made to LASA's budget flowing from a decrease in the Department of Justice and Constitutional Development's allocation from the national fiscus. LASA had already had its funding from government reduced by $5 \%$ in the 2018-19 financial year alone, with a further huge budget cut of 503 million Rand promised over the next three years. ${ }^{56}$ The government is unquestionably faced with significant financial limitations in terms of its service delivery mandate, but such cutting of legal aid funding is counter-productive in terms of the aforementioned "leverage right" element of improved access to justice and the enjoyment of other rights through legal aid. The cut should therefore be urgently reconsidered.

Relevant to the question of the likely impact of law community service, but to be weighed up with the logistics for its introduction, will be whether community service in South Africa should be a compulsory element of vocational training. Alternatively, community service could be one possible route towards qualification as a lawyer, or it could be initially piloted. Also to be considered is whether it would be performed immediately on graduation or one year after graduation, after one year's vocational training has been performed. These matters would need to be included in the necessary regulations for graduate community service pertaining to section 29 of the LPA. Although they are not insignificant, their consideration should not be allowed to stop the introduction of an appropriate graduate community service scheme. Changes to the decision as to what would be required of and applicable to graduates would always be possible.

56 Mabuza 2018 https://www.timeslive.co.za/news/southafrica/2018-10-17-legal-aidsa-budget-cuts-bad-news-for-poor-and-vulnerable-seeking-justice/. 


\section{Conclusion}

This paper has argued that law graduate community service could and should be a valuable element of the provision of civil legal aid in South Africa for improved access to justice to a very large proportion of the population for whom the promises of the legal system remain elusive. There has not been an attempt to provide all the solutions as to how community service for law graduates should be rolled out and run. Key factors requiring consideration have been raised and some proposals made as to how they might be addressed. What is now required is to come up with means to effectively establish and run such a system.

Mechanisms are necessary for proper graduate supervision, the appropriate placement of graduates, and sufficient resource allocation. An inappropriately run scheme could have various seriously negative effects, such as those arising from the inadequate vocational training of graduates, wasted state resources and, most problematically, placing vulnerable members of the public at risk of a poor standard of legal services.

A broader study has called for a multi-faceted and well-coordinated approach to free legal service provision in civil matters for the indigent in South Africa, which could sensibly include community service. ${ }^{57}$ Whilst it would be far from a silver bullet to sufficiently increase South African civil legal aid service delivery, the introduction of properly implemented and run community service may be a key ingredient in greater service delivery.

\section{Bibliography}

\section{Literature}

Holness Coordinating Free Legal Services

Holness D Coordinating Free Legal Services in Civil Matters for Indigent People in eThekwini: A Model for Improved Access to Justice (Doctoral thesis Nelson Mandela (Metropolitan) University 2015)

Holness 2013 JJS

Holness D "The Need for Recognition and Regulation of Paralegals: An Analysis of the Roles, Training, Remuneration and Impact of Community Based Paralegals in South Africa" 2013 JJS 78-105 
Holness 2013a PELJ

Holness D "Improving Access to Justice through Compulsory Student Work at University Law Clinics" 2013 PELJ 328-349

Holness 2013b PELJ

Holness D "Recent Developments in the Provision of Pro Bono Legal Services by Attorneys in South Africa" 2013 PELJ 129-164

Holness 2013 SJ

Holness D "The Constitutional Justification for Free Legal Services in Civil Matters in South Africa" 2013 SJ 1-21

Kautzky and Tollman 2008 SAHR

Kautzky K and Tollman S "A Perspective on Primary Health Care in South Africa" 2008 SAHR 17-30

Manyathi-Jele 2013 De Rebus

Manyathi-Jele N "The Legal Practice Bill and Community Service" 2013 De Rebus 8-10

McQuoid-Mason 1999 Windsor YB Access Just

McQuoid-Mason D "Access to Justice in South Africa" 1999 Windsor YB Access Just 1-16

Omole, Maricowitz and Ogunbanjo 2005 SAFP

Omole O, Maricowitz $G$ and Ogunbanjo G "Perceptions of Hospital Managers Regarding the Impact of Dr's Community Service" 2005 SAFP $55-59$

Padfield 2013 PPSA

Padfield L "Reframing the Frame: Reflections of a Community Service Psychologist" 2013 PPSA 61-92

Perold and Omar Community Service in Higher Education

Perold $\mathrm{H}$ and Omar R Community Service in Higher Education: A Concept Paper (Joint Education Trust Johannesburg 1997)

Pillay and Harvey 2006 SAJP

Pillay A and Harvey B "The Experiences of the First South African Community Service Clinical Psychologists" 2006 SAJP 259-280

Rohleder, Miller and Smith 2006 SAJP

Rohleder P, Miller M and Smith R "Doing Time: Clinical Psychologists' Experience of Community Service in a Prison Placement" 2006 SAJP 795812 
Van As 2005 Obiter

Van As $\mathrm{H}$ "Taking Legal Aid to the People: Unleashing Local Potential in South Africa" 2005 Obiter 187-206

Vawda 2005 Obiter

Vawda $Y$ "Access to Justice: From Legal Representation to Promotion of Equality and Social Justice - Addressing the Legal Isolation of the Poor" 2005 Obiter 234-247

\section{Legislation}

Constitution of the Republic of South Africa, 1996

Legal Practice Act 28 of 2014

Legal Practice Amendment Act 16 of 2017

\section{Government publications}

GN 627 in GG 40955 of 30 June 2017 (National Health Insurance Policy)

GN R921 in GG 41879 of 31 August 2018

\section{Register of internet sources}

Chaskalson 1997 http://www.derebus.org.za/category/issues/December1997/

Chaskalson A "Legal Interns Could Solve Legal Aid Problems" 1997 (Dec) De Rebus 782 http://www.derebus.org.za/category/issues/December-1997/ accessed 14 January 2013

Conco and Reid 2012 http://www.hst.org.za/uploads/files/chapter17_99pdf Conco D and Reid S 2012 Monitoring the Implementation of Community Service http://www.hst.org.za/uploads/files/chapter17_99pdf accessed 30 December 2013

De Vos 2007 https://dullahomarinstitute.org.za/socio-economicrights/research-and-publications/resource-book/Chapter\%208\%20$\% 20$ Health\%20Care\%20Rights.pdf

De Vos P "Health Care Rights" in Khoza S (ed) Socio-Economic Rights Resource Book $2^{\text {nd }}$ ed (Dullah Omar Institute Cape Town 2007) ch 8 https://dullahomarinstitute.org.za/socio-economic-rights/research-andpublications/resource-book/Chapter\%208\%20-

\%20Health\%20Care\%20Rights.pdf accessed 16 January 2012 
Department of Health 2006 http://www.doh.gov.za/ docs/pr/2006/pr0105.html

Department of Health 2006 Community Service to Improve Access to Quality healthcare to All South Africans http://www.doh.gov.za/docs/ pr/2006/pr0105.html accessed 2 October 2012

Department of Health 2019 http://phila.org.za

Department of Health 2019 PHILA http://phila.org.za/ accessed 10 December 2019

Government of the Republic of South Africa 2017 https://www.gov.za/issues/national-development-plan-2030

Government of the Republic of South Africa 2017 National Development Plan 2030 https://www.gov.za/issues/national-development-plan-2030 accessed 10 December 2019

LASA 2017 http://www.legal-aid.co.za/wp-content/uploads/2017/09/ANRLegal-Aid-SA_2017.pdf

Legal Aid South Africa 2017 Legal Aid South Africa Integrated AnnualReport 2016/2017 http://www.legal-aid.co.za/wp-content/uploads/2017 /09/ANR-Legal-Aid-SA_2017.pdf accessed 6 August 2018

LRC 2018 http://lrc.org.za/contact/

Legal Resources Centre 2018 Contact Us http://lrc.org.za/contact/ accessed 11 August 2018

Mabuza 2018 https://www.timeslive.co.za/news/southafrica/2018-10-17legal-aid-sa-budget-cuts-bad-news-for-poor-and-vulnerable-seekingjustice/

Mabuza E 2018 "Legal Aid SA Budget Cuts Bad News for Poor and Vulnerable Seeking Justice" Times Live (17 October 2018) https://www.timeslive.co.za/news/southafrica/2018-10-17-legal-aid-sa-

budget-cuts-bad-news-for-poor-and-vulnerable-seeking-justice/ accessed 20 January 2019

PHILA 1996 http://www.healthlink.org.za/pphc/Phila/mandserv.htm PHILA 1996 Legislative Update; SAMJ: HealthLink http://www.healthlink. org.za/pphc/Phila/mandserv.htm accessed 20 September 2013

Witsvuvuzela 2012 http://witsvuvuzela.com/2012/09/27/new-law-forlawyers/

Witsvuvuzela 2012 New Law for Lawyers http://witsvuvuzela.com/2012/09/27/new-law-for-lawyers/ accessed 10 October 2013 


\section{List of Abbreviations}

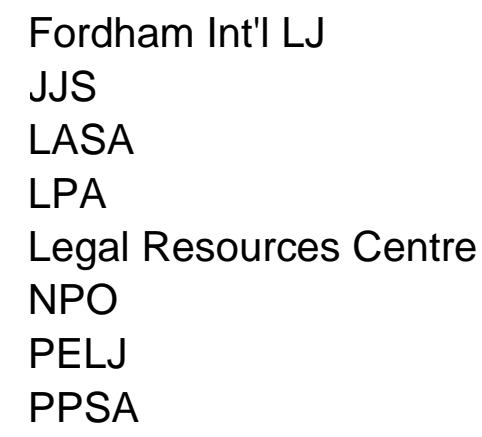

SJ

SAFP

SAHR

SAMJ

SAJP

Windsor YB Access Just
Fordham International Law Journal Journal of Juridical Science

Legal Aid South Africa

Legal Practice Act

LRC

Non-profit organisation

Potchefstroom Electronic Law Journal

Psycho-analytic Psychotherapy in South Africa

Speculum Juris

South African Family Practice

South African Health Review

South African Medical Journal

South African Journal of Psychology

Windsor Yearbook of Access to Justice 